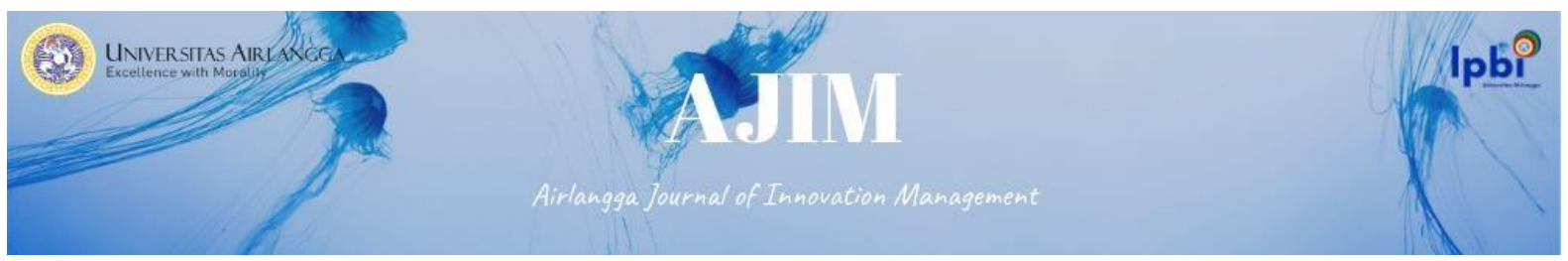

Vol. 2 No.2 Oktober 2021

e-ISSN: 2722-5062

DOI : 10.20473/ajim.v\%vi\%i.31124

\title{
INFORMATION SYSTEM DESIGN AND INVENTORY MANAGEMENT ON PHARMACY BUSINESS WITHIN ABC-XYZ ANALYSIS METHOD
}

\author{
Christopher Amadeus Herlambang ${ }^{a^{*} \text {, Joniarto Parung }}{ }^{\mathrm{b}}$ \\ ${ }^{a, b}$ Faculty of Business and Economics, University of Surabaya \\ ${ }^{*}$ Corresponding e-mail : christopheramadei@gmail.com
}

\begin{abstract}
Inventory will difficult to be controlled when there is an increase on product item number. It needs product grouping analysis to determine product priorities. So that, an inventory management information system that supports inventory planning process becomes important to discuss. The same problem is also experienced by Kutisari pharmacy which has nearly 1500 product items that controlled by conventional-based stock and inventory recording system. Based on observations pharmacy planning is currently done based on the owner subjectivity. The expired goods is often became problem because control system is still conventional and number of product items is quite large. Researchers classify products in various stages with final result being a combination of $\mathrm{ABC}$ and $\mathrm{XYZ}$ classifications. The demand data for priority products is forecasted according to the model that gives best MAPE/MSD results and researcher improves inventory management system flow by implementing an inventory management information system at Kutisari Pharmacy. After that, an analysis is carried out to find out benefits of application system. Based on data analysis, losses from expired drugs and goods that are not recorded in warehouse resulted in lost sales of Rp. 3,312,000 in a year. In future this losses could be prevented and minimized, so that it can be benefits for pharmacy business.
\end{abstract}

\section{Keywords: Inventory Management, Pharmacy Business, ABC and XYZ classification, Total Potential Revenue.}

\section{Introduction}

One of the sectors affected by industrial revolution is pharmaceutical business. Definition of Pharmacy according to Big Indonesian Dictionary (KBBI) is the method and technology of making drugs as well as ways of storing, providing, and distributing them. One of things that becomes an important focus in pharmaceutical sector is stock management of drugs in a health facility. Pharmaceutical health facilities in this case can include hospitals, clinics, pharmacies, so that technological changes also have an impact on stock management of these pharmaceutical preparations (Kominfo, 2020). Pharmaceutical facilities that are close to the community and society are pharmacies. Based Indonesian Pharmacy Recapitulation (Kementerian Kesehatan RI, 2018) data in 2015 there were 25,339 pharmacies in Indonesia, while in 2018 there was an increase in the number to 26,658 pharmacies. So, it can be concluded that during last 3 years, number of pharmacies in Indonesia has 


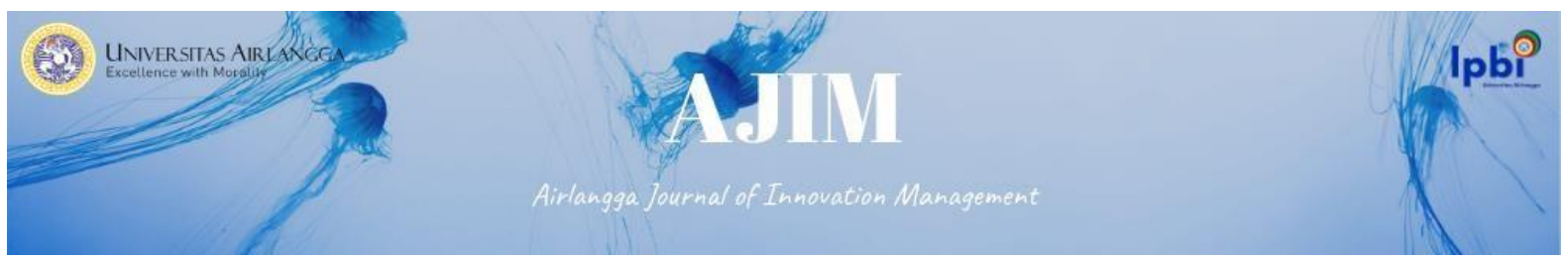

grown by $2.54 \%$. In 2018 Indonesian Pharmacy Recapitulation data, three provinces with highest number of pharmacies in a row are West Java (4298 pharmacies), East Java (3674 pharmacies) and Central Java (3395 pharmacies).

Table 1. Number of Health Service Facilities in Surabaya

\begin{tabular}{|r|l|c|}
\hline \multicolumn{1}{|c|}{ No. } & Healthcare Facilities & Total Units \\
\hline 1 & Pharmacy & 762 \\
\hline 2 & Primary Clinic & 233 \\
\hline 3 & Main Clinic & 103 \\
\hline 4 & Optical & 99 \\
\hline 5 & Laboratory & 69 \\
\hline 6 & Puskesmas & 63 \\
\hline 7 & Hospital & 59 \\
\hline
\end{tabular}

(Dinas Kesehatan Kota Surabaya, 2018)

The increase in number of pharmacies in Indonesia has resulted in increased competition in pharmacy sector. This makes pharmacy entrepreneurs to innovate in their business. Hutasoit, (2018) researching a web-based drug inventory information system at a pharmacy in Jakarta. Pharmacy has a conventional data processing system, Hutasoit (2018) developed a web-based information system so that drug procurement activities can be carried out effectively and minimize errors. Results of those research obtained that this information system data processing can be done quickly, precisely and accurately.

Inventory management at a pharmacy is one of important factors in continuity of this business, due to many types of medicinal products and several drugs whose use is specific for certain treatments, so that availability of drug stocks in pharmacies must be ensured to be well maintained. One approach that can be used for inventory management is to classify products with $\mathrm{ABC}-\mathrm{XYZ}$ analysis. ABC-XYZ classification approach for inventory optimization carried out by Trubchenko et al., (2020). It shows that $\mathrm{ABC}-\mathrm{XYZ}$ classification can significantly reduce the cost of storing goods, optimizing storage area and focusing on stable products and increasing demand. Krishnaraj \& K, (2016) stated that conducted an ABC-XYZ analysis study at pharmacy in a special pediatric hospital in India, in order to make improvements to pharmacy. The results of study recommend that $\mathrm{ABC}-\mathrm{XYZ}$ analysis be carried out routinely at pharmacies and results of analysis can be used as considerations in making purchases, storage, investment and monitoring of pharmacy inventory.

The research data was obtained from Kutisari pharmacy which still uses conventional system. Kutisari pharmacies often have difficulty meeting drug requests because there is no procurement plan based on data. The research was conducted by implementing a web-based drug inventory information system in conventional pharmacies and an inventory management approach by classifying products in pharmacies with $\mathrm{ABC}-\mathrm{XYZ}$ analysis. So that inventory control and pharmacy stock can be carried out based on data obtained by using information systems and planning based on ABC-XYZ analysis. This paper is an applicative research result for: a) Improved pharmacy inventory flow at Kutisari pharmacy; b) Doing stock planning at Kutisari Pharmacy based on forecasts with time-series models; and c) Designing and implementing an inventory management information system at Kutisari pharmacy. 


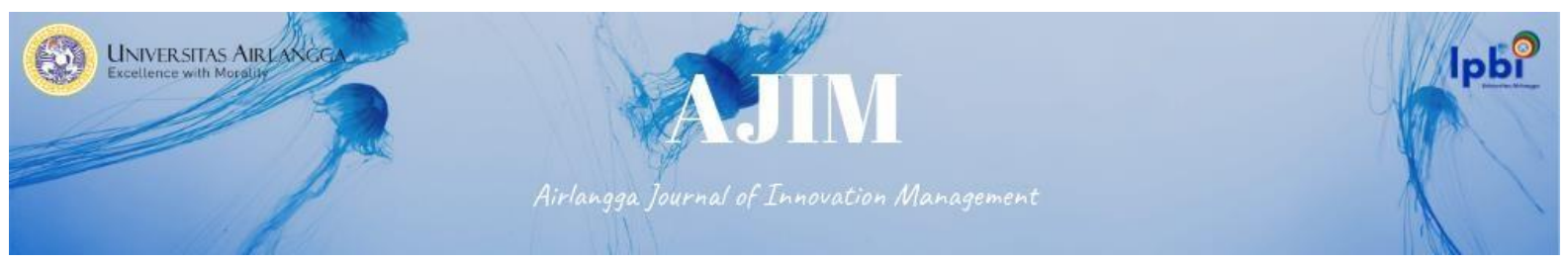

\section{Literature Review \\ Product Classification}

Companies that have a large number of items, often face difficulties in managing their inventory system, because characteristics of each item are different in demand, price and dimensions of each item. In order for focus of inventory management to have an influence on the right product, products are grouped into various classifications (Noordstar et al., 2019) Product Classification which is generally used are as follows:

\section{a. ABC Classification}

$\mathrm{ABC}$ analysis is used to determine inventory management priorities. Inventories are categorized into classes A, B and C. Attention and management efforts are prioritized to class A inventories, while class $C$ gets least attention and class B is between A and B. (Ravinder \& Misra, 2014). ABC analysis is done by separating the product into 3 classifications based on the value (Ernst \& Cohen, 1990). The provisions of $\mathrm{ABC}$ classification are as follows:

- Class $\mathrm{A}$ is a product that has a cumulative value of multiplying $70 \%$ of total value.

- Class B is a product that has a cumulative value of multiplication of $20 \%$ of total value.

- Class $\mathrm{C}$ is a product that has a cumulative value of multiplication of $10 \%$ of total value Class A and B generally can use the Economic Order Quantity (EOQ) model, while for class C generally can use a simple inventory control model, namely red line method. (Utama, 2019).

\section{b. XYZ Classification}

Monetary value is not the only criterion for classifying products. Several other criteria that can be used for consideration include physical volume, demand patterns or delivery times (Ivanov \& Tsipoulanidis, 2019). If using physical volume of a product item, then the XYZ classification will be as follows:

- Class X: Large-sized product.

- Class Y: Medium-sized product.

- Class Z: Small products that can be carried with humans.

XYZ classification based on market demand by looking at value of coefficient of variation (C.V), then XYZ classification will be as follows (Kumar, 2017; Nowotyńska, 2013; Scholz-Reiter et al., 2012):

- Class X: Products with constant demand with a value $(C . V<0.3)$ so that accuracy of forecasting is high

- Class Y: Products with medium fluctuation demand with values $(0.3<\mathrm{CV}<0.56)$ so that accuracy of forecasting is in the medium size (sometimes accurate, sometimes not)

- Class Z: Products with high fluctuation demand $(\mathrm{C} . \mathrm{V}>0.56)$ so that accuracy of forecasting is very low.

Classification with $\mathrm{XYZ}$ analysis aims to find out which inventory has a more constant demand fluctuation or has an uncertain amount of demand. Information from XYZ analysis can be used to develop strategies in calculating reorder points, and determining inventory control time intervals.

\section{c. Combination of ABC-XYZ Analysis}

$\mathrm{ABC}$ analysis has limitations that can be complemented by $\mathrm{XYZ}$ analysis which adds average variable of demand fluctuations. Combination of these two analyzes helps in determining purchase method for each inventory classification and determining what products should always be in stock, when a product must be ordered JIT, and when a product is ordered according to forecast results. (Ivanov \& Tsipoulanidis, 2019; Stojanović \& Regodić, 2017) 


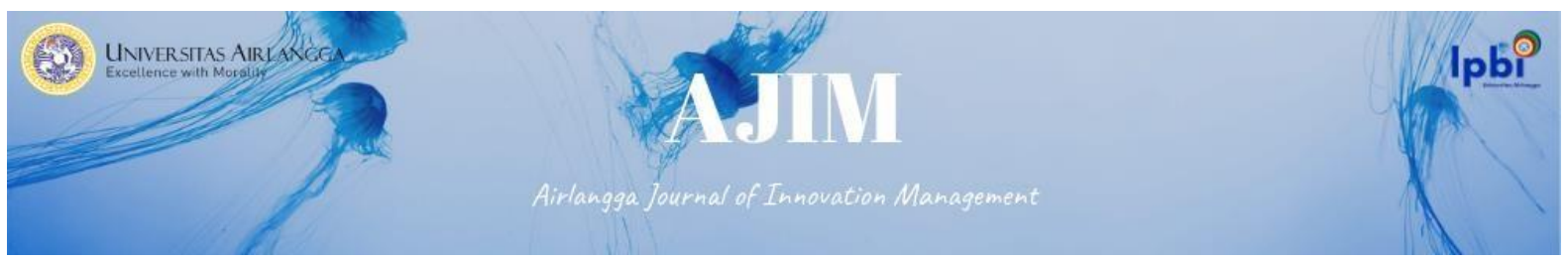

$\mathrm{ABC}-\mathrm{XYZ}$ analysis matrix can be seen in figure below, where $\mathrm{X}$ is categorized as a product with constant demand, $\mathrm{Y}$ is a product with fluctuating market demand and $\mathrm{Z}$ is a product with sporadic or very erratic demand.

Part Characteristics in the Combined ABC-XYZ-Matrix [24]

\begin{tabular}{|c|l|l|l|}
\hline & \multicolumn{1}{|c|}{ A } & \multicolumn{1}{c|}{ B } & \multicolumn{1}{c|}{ C } \\
\hline $\mathbf{X}$ & $\begin{array}{l}\text { high value, } \\
\text { high predictability } \\
\text { continuous demand }\end{array}$ & $\begin{array}{l}\text { medium value, } \\
\text { high predictability } \\
\text { continuous demand }\end{array}$ & $\begin{array}{l}\text { low value, } \\
\text { high predictability } \\
\text { continuous demand }\end{array}$ \\
\hline $\mathbf{Y}$ & $\begin{array}{l}\text { high value, } \\
\text { medium predictability } \\
\text { fluctuating demand }\end{array}$ & $\begin{array}{l}\text { medium value, } \\
\text { medium predictability } \\
\text { fluctuating demand }\end{array}$ & $\begin{array}{l}\text { low value, } \\
\text { medium predictability } \\
\text { fluctuating demand }\end{array}$ \\
\hline $\mathbf{Z}$ & $\begin{array}{l}\text { high value, } \\
\text { low predictability } \\
\text { irregular demand }\end{array}$ & $\begin{array}{l}\text { medium value, } \\
\text { low predictability } \\
\text { irregular demand }\end{array}$ & $\begin{array}{l}\text { low value, } \\
\text { low predictability } \\
\text { irregular demand }\end{array}$ \\
\hline
\end{tabular}

Figure 1.ABC-XYZ Analysis (Stojanović \& Regodić, 2017)

$\mathrm{ABC}-\mathrm{XYZ}$ analysis matrix will describe priority of products that get stricter management than other categories. Products that are included in AX category will receive top priority because better forecasts can be made and are products that are included in category A which have a large product value. (Pratama Wijaya et al., 2015) and ABC-XYZ classification should be done monthly, or annually according to type of industry (Timm Gudehus, 2006).

\section{Forecasting}

Hyndman \& Athanasopoulos, (2018) stated that forecasting is an activity of predicting future as accurately as possible, using all available information, including historical data, experience and knowledge of future events that may affect forecasts. Wang \& Chaovalitwongse, (2011) categorizes forecasting in general in 2 approach methods, namely qualitative methods and quantitative methods which can be seen in diagram below.

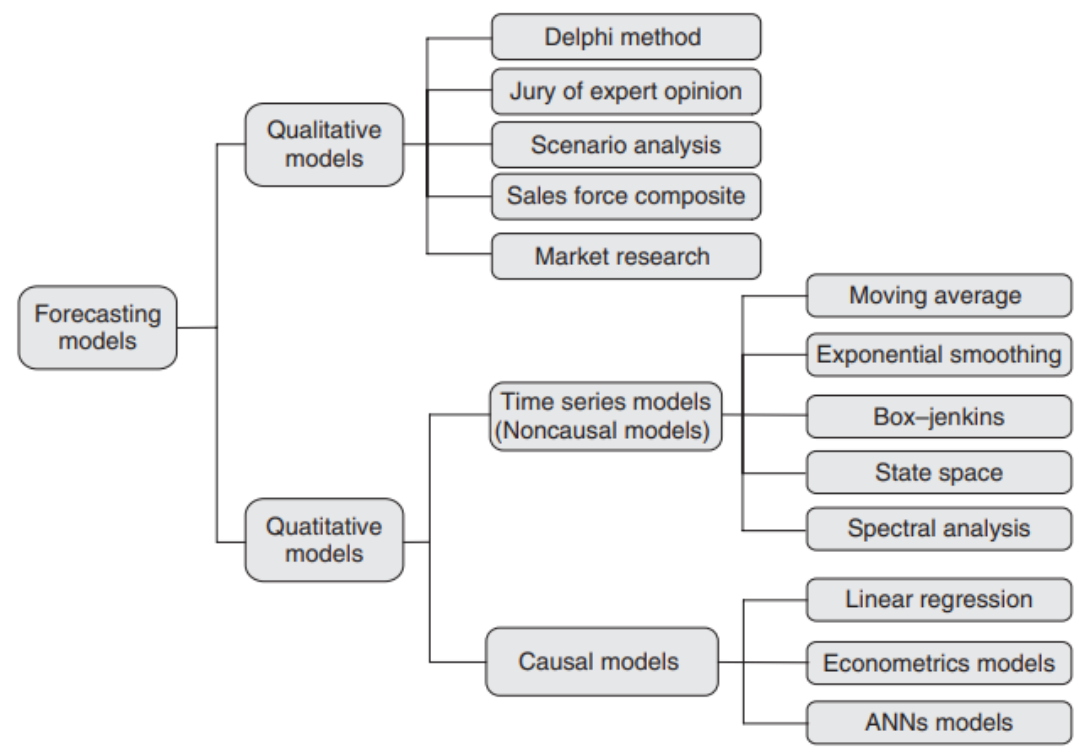

Figure 2. Forecasting Model Categorization Diagram

Source: (Wang \& Chaovalitwongse, 2011) 


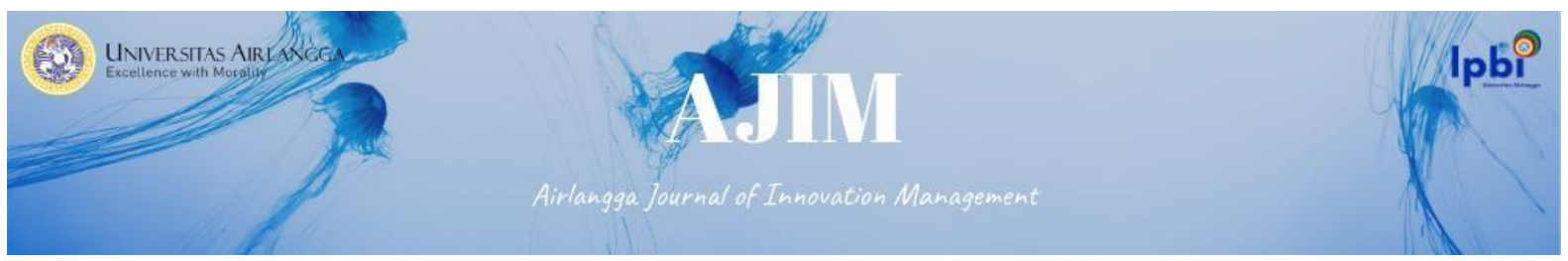

\section{Methods/Materials}

The primary and secondary data collection used in this study were observation and interviews. Observations are made by looking at business processes that occur at Kutisari Pharmacy and collecting data from various sources including sales data per product item, product lead time data, lost sales data and expired items. Interviews were conducted in-depth by classifying problems in business processes at Kutisari Pharmacy.

The research model of this study will redesign business process flow, especially in inventory management and make improvements to priorities for controlling inventory needs at Kutisari Pharmacy, using an inventory management information system improvement approach and process flow improvement as well as the $\mathrm{ABC}-\mathrm{XYZ}$ classification approach and time-series forecasts model. The following is the process flow of the research in determining the design of management information systems in pharmacies and planning calculations based on ABC-XYZ Analysis:

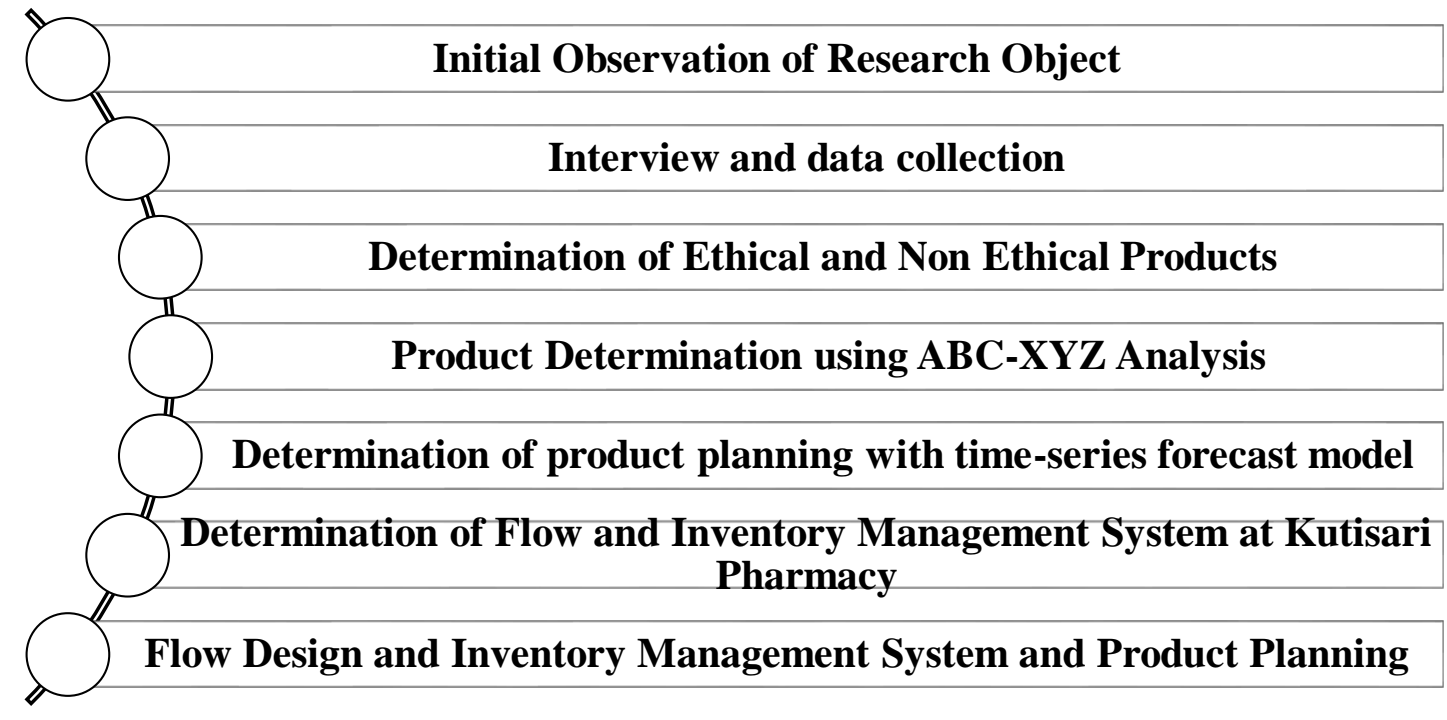

Figure 3. Inventory Management System Design Process Flow and Product Planning Process Source: Research result (2021)

\section{Results and Discussion}

\section{Interviews with pharmacy staff and pharmacy owners}

Interview process was conducted by asking 5 employees (including the owner) of Kutisari pharmacy about problems encountered in inventory management process. Interview result shows there are several similar answers, which will be recapitulated into one. The following are results of interviews that have been carried out, problem of inventory management in pharmacies that most often occurs is due to manual recording of goods so that it is prone to errors. 


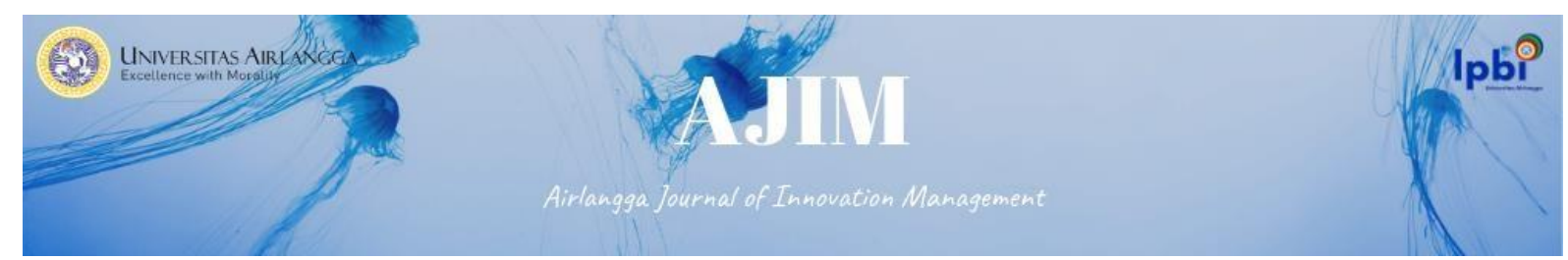

Table 2. Interview Results at Kutisari Pharmacy

\begin{tabular}{|c|l|c|}
\hline No. & \multicolumn{2}{|c|}{ Interview Results } \\
\hline \multicolumn{2}{|c|}{ Inventory Problems in Pharmacy } & Total \\
\hline 1. & Recording system of inventory are manual so it is prone to error & 5 \\
\hline 2. & Goods Checking in warehouse is done manually & 4 \\
\hline 3. & $\begin{array}{l}\text { The sales process is carried out manually from sales to the finance } \\
\text { department (starting from selling goods to receiving payments) }\end{array}$ & 4 \\
\hline 4. & $\begin{array}{l}\text { The drug procurement process is carried out in a "feeling" from the } \\
\text { pharmacy owner without a clear plan }\end{array}$ & 3 \\
\hline
\end{tabular}

Source: Interview Result (2021)

\section{Flow Design and Inventory management information system}

From results of observations and interviews obtained related to system and flow that has been applied, thing to do is analyze a system and flow. The analysis is carried out based on problems that arise in application of existing system and flow. Each of these problems is searched for cause of problem and a decision point is made to overcome problem. Decision point will be included in consideration of designing an inventory management information system, from interview results there are two design flows that will be redesigned:

\section{a. System for recording and flow of purchase and receipt of products from suppliers}

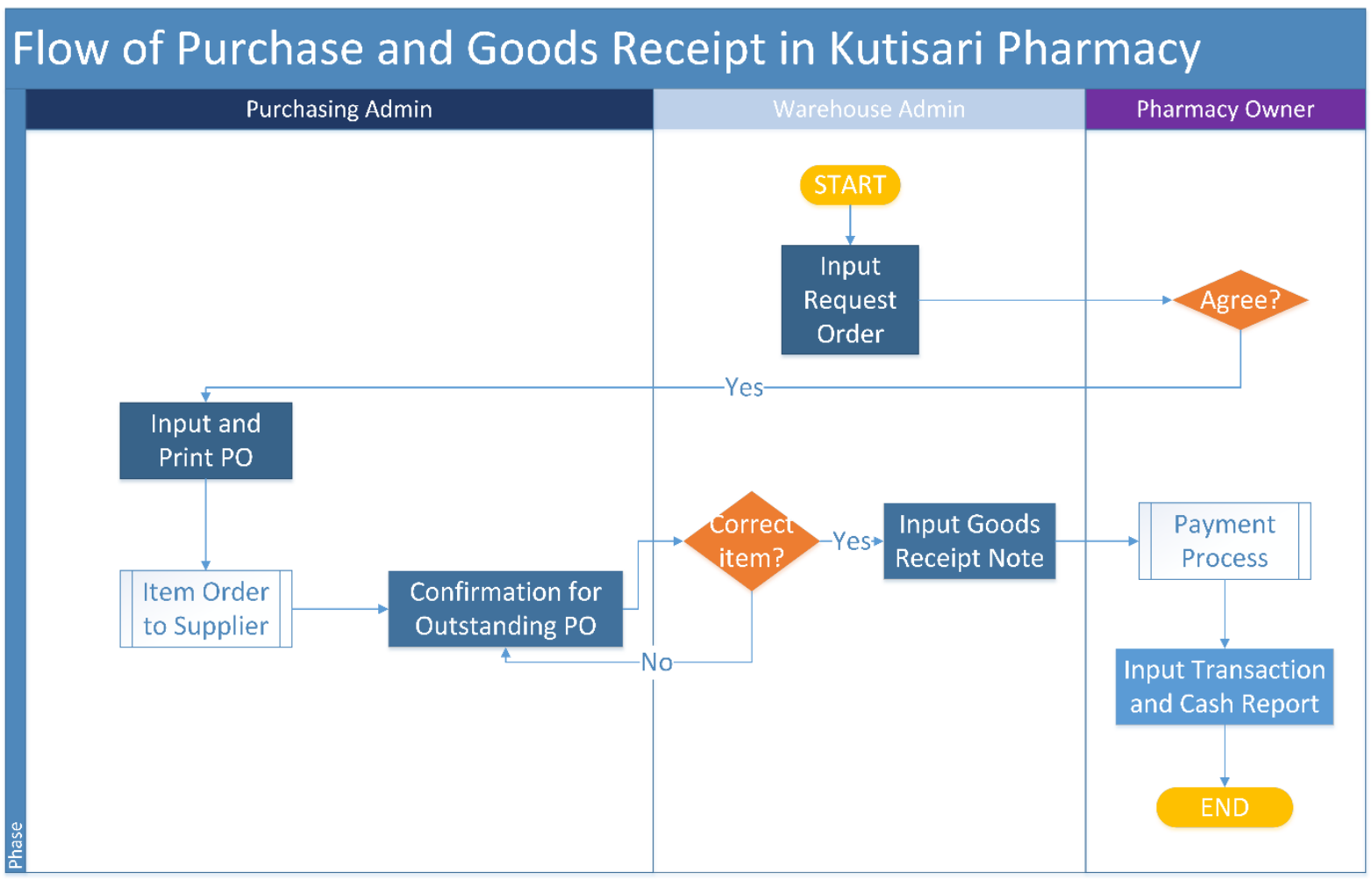

Figure 4. Flowchart of Order Process and Receipt of goods at Kutisari Pharmacy

Source: Research result (2021) 


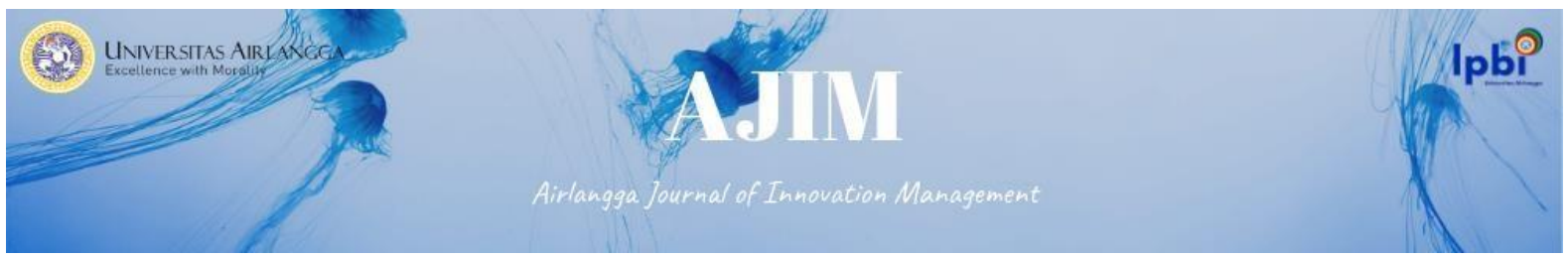

The process flow for purchasing and procuring products at Kutisari Pharmacy is as follows:

1. Warehouse staff will submit a request to purchase goods to pharmacy owner if there is a product stock that has reached the minimum stock.

2. Pharmacy owner will check request for purchase of goods submitted by warehouse staff, if appropriate, request will be submitted to purchasing staff.

3. Purchasing staff will make a Letter of Order or purchase order via software to suppliers who have requested product.

4. Purchasing staff checks regularly every day PO outstanding (orders that have not been received by Warehouse admin).

5. When goods from supplier arrive, warehouse staff will receive and check suitability of the product coming from the supplier,

6. The warehouse staff will input amount of stock, product name and product expiration limit in software and print receipt of goods

7. Warehouse staff inform purchasing admin that goods have been received and are appropriate. If there is a discrepancy in order, Warehouse admin will communicate to supplier about product that is not suitable, and purchasing admin will still assume PO status of product is still unavailable

8. If there is a discrepancy in order, Warehouse admin will communicate to supplier about product that does not match, and purchasing admin will still assume PO status of product is still outstanding.

9. Supplier will print order invoice and pharmacy owner will pay off purchase of product in accordance with agreement with supplier, The owner of pharmacy is responsible for input process of settlement transaction in software

b. Recording system and product sales flow to customers

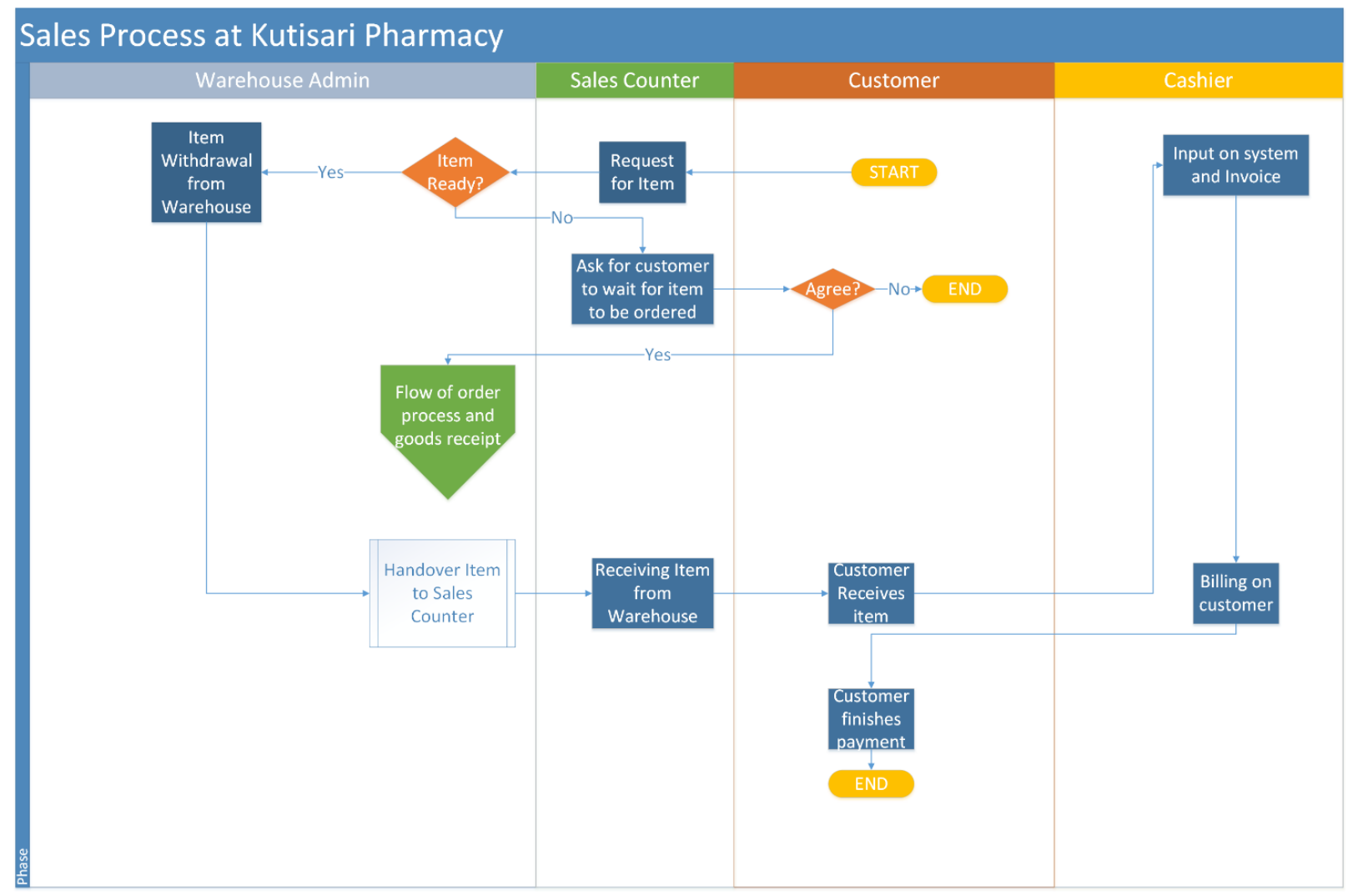

Figure 5. Flowchart of the Sales Process at Kutisari Pharmacy

Source: Research result (2021) 


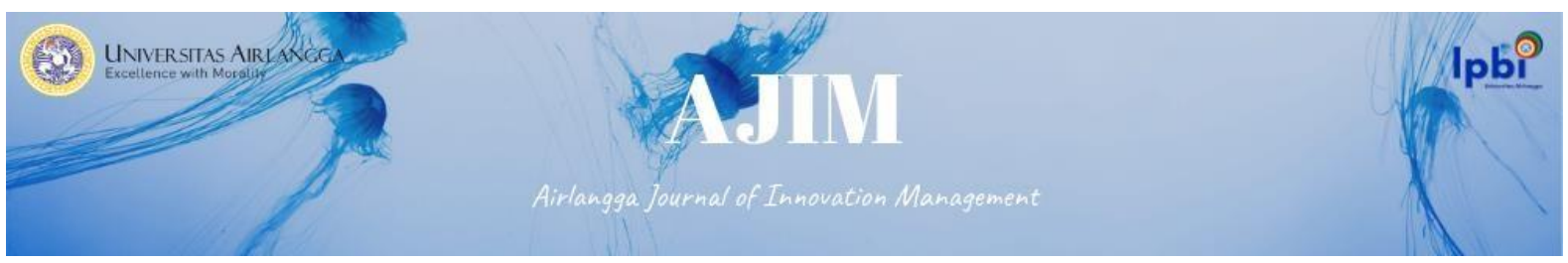

Sales activities at the Kutisari pharmacy are a form of business to customer, so business processes occur directly with customers. The sales process at the Kutisari pharmacy involves four parties, namely the customer, the sales counter staff, the warehouse staff, and the cashier staff. The sales flow that will be carried out at the Kutisari pharmacy is as follows:

1. Customers come to pharmacy to buy drugs or redeem prescriptions at pharmacy.

2. The sales counter staff will welcome and serve customers who come to pharmacy.

3. The sales counter staff will ask warehouse staff for availability of drug stock or prescription

4. Warehouse staff will prepare drug requests or prescriptions from customers if requested drugs and products are available

5. Warehouse staff will hand over drug or prescription to sales counter staff, then it will be handed over to customer

6. If request for a drug or prescription cannot be fulfilled due to unavailability of stock, warehouse staff will inform the unavailability of drug or product to sales counter staff

7. Sales counter staff will offer customers an offer for drug substitution or offer to wait for drug to be held at Kutisari pharmacy

8. Cashier staff will inform price and total customer purchases. If customer agrees, cashier will input billing in POS system, and print a receipt/invoice to customer.

9. Customer pays off according to invoice made

\section{Product Requirements Classification and Planning}

Product classification

Figure 6. Classification of Products

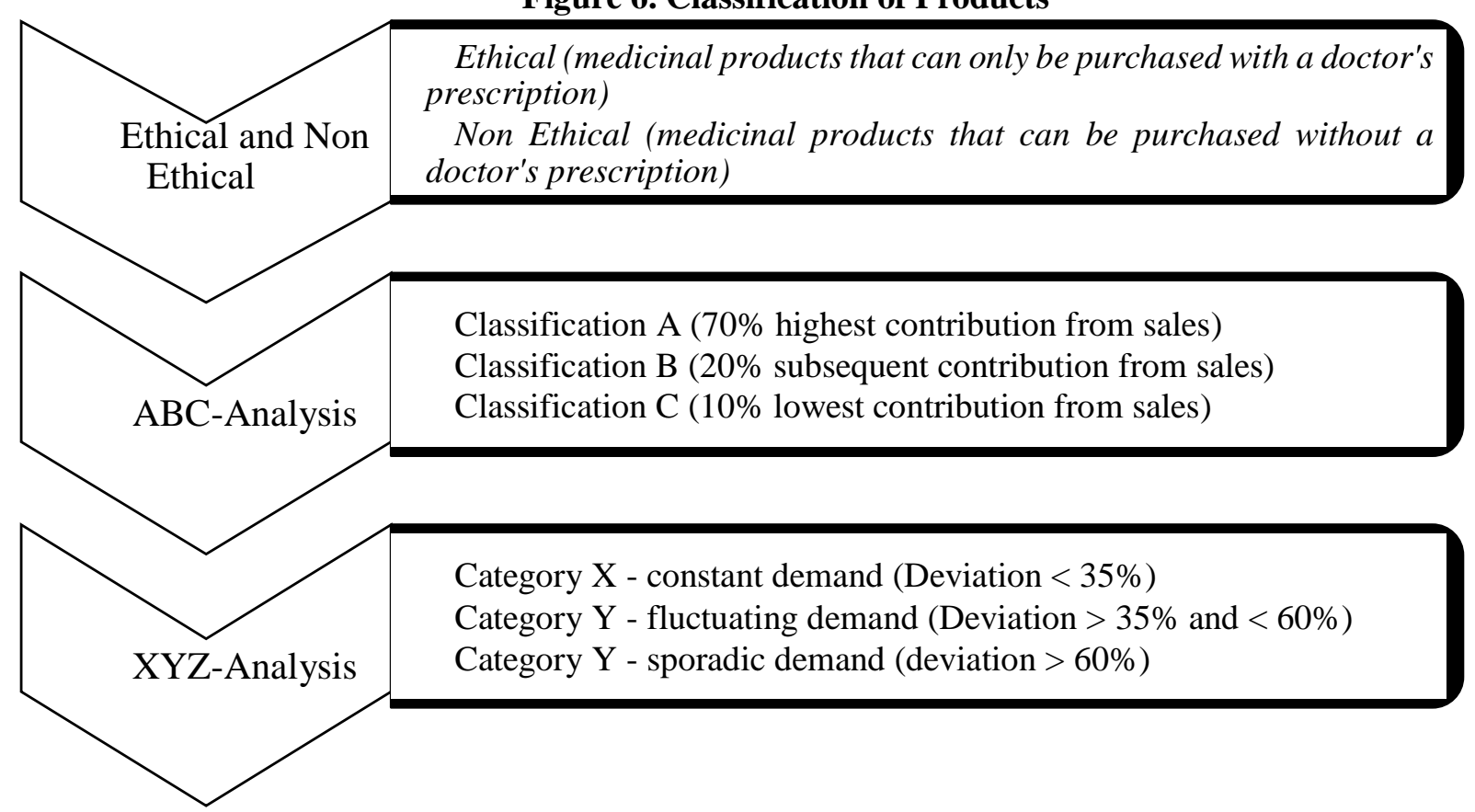

Source: Research result (2021)

Based on observations and interviews results, there are problems with inventory at Kutisari Pharmacy, such as number of product items that are managed, types of drugs based on regulations (certain drugs cannot be sold freely), product availability at suppliers, and stock procurement using owner habits, thus causing a buildup of stock and cash flow from pharmacy is not good. In this study, 


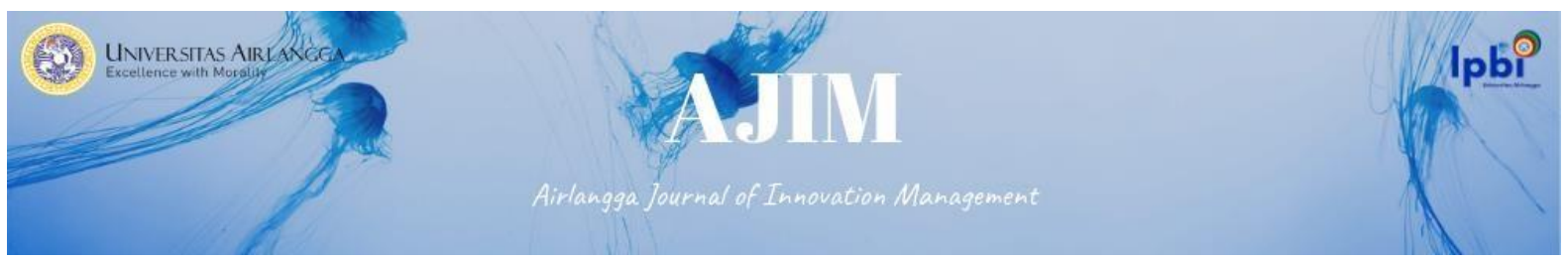

it aims to provide a solution to this problem, so that a system is created that can help pharmacy team when carrying out inventory management, namely by grouping products.

\section{a. Ethical and Non-Ethical Classification}

Kutisari Pharmacy currently has 1375 types of medicinal products, which include Ethical and NonEthical Medicines. After grouping the drug products, following results are obtained:

a. Ethical products: 356 products

b. non-ethical products: 1021 products.

From these results, 356 ethical products contributed greater sales compared to non-ethical products, which was $61.42 \%$ of total sales, because sales contribution of ethical products was considered not yet able to represent overall sales contribution, so it was considered to include 5 non-ethical products with highest sales contribution so that total drugs that will be further classified are 361 products with details of 356 ethical products and 5 non-ethical products so that total contribution of these products is $67.07 \%$. b. ABC Classification

After process of separating product items between ethical and non-ethical products, researchers will regroup the 361 ethical products using $\mathrm{ABC}$ classification formula and results of the grouping are obtained as shown in the table below:

Table 3. ABC Analysis Table

\begin{tabular}{|c|r|c|}
\hline Category & \% Value & Total item \\
\hline A & $70 \%$ & 72 \\
\hline B & $20 \%$ & 58 \\
\hline C & $10 \%$ & 231 \\
\hline
\end{tabular}

Source: Research result (2021)

From items that are included in category A, there are items that are categorized as a slow-moving because some items are needed specifically to treat some condition or disease and as a healthcare facility it is a social responsibility to keep those items for patients because of that the XYZ classification refines the $\mathrm{ABC}$ classification for slow moving items by analyzing the demand fluctuation of those items.

\section{c. XYZ Classification}

From the results of the $\mathrm{ABC}$ analysis, the researcher will regroup the products as many as 72 items that are included in category $\mathrm{A}$, these products will be classified using the $\mathrm{XYZ}$ method and the grouping results are as in the table below:

Table 4. XYZ analysis table

\begin{tabular}{|c|c|c|}
\hline Category & Demand Fluctuation & Total item \\
\hline $\mathrm{X}$ & $<35 \%$ & 14 \\
\hline $\mathrm{Y}$ & $<60 \%$ & 17 \\
\hline $\mathrm{Z}$ & $>60 \%$ & 41 \\
\hline
\end{tabular}

Source: Research result (2021)

From the results of the product grouping, 14 products are obtained which will then be made forecast based on sales history data using the existing modeling in the Minitab program 


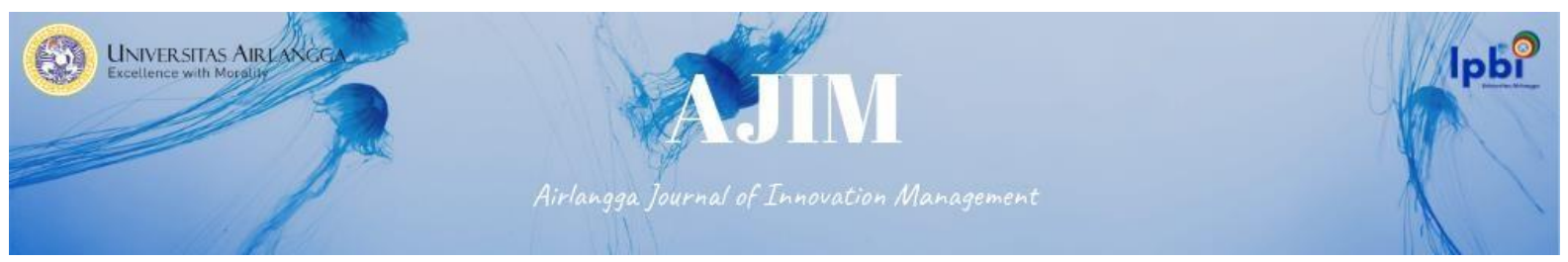

\section{Forecast and Stock Planning}

Sales forecasts are made for each product by analyzing each product using minitab modeling. The forecast results from each model will see MAPE, MAD and MSD values from minitab processing and from these values lowest error value is taken. The model that has lowest MAPE, MAD and MSD will be compared with total sales to re-analyze whether selected forecast figures are in accordance with number of requests in last 2 years. If forecast figures deviate much, we will look again at other timeseries type models, which are closest to total sales for last 2 years.

After obtaining forecast result analysis of each of these products, stock planning of each product will then be carried out to meet demand at pharmacy for one month. The planning of each product is carried out by considering minimum order quantity obtained from each vendor in order to obtain maximum discount for prices of these products and the calculation of buffer stock, stock planning for priority products can be seen in table below

Table 5. Product Stock Planning Table for next 1 month

\begin{tabular}{|c|c|c|c|c|c|c|}
\hline No & Product Name & $\begin{array}{c}\text { Forecast } \\
\text { Results }\end{array}$ & $\begin{array}{c}\text { Minimum } \\
\text { Stock }\end{array}$ & $\begin{array}{l}\text { Buffer } \\
\text { Stock }\end{array}$ & $\begin{array}{l}1 \text { Month } \\
\text { Planning }\end{array}$ & $\begin{array}{c}\text { Minimum Order } \\
\text { Quantity } \\
\text { Adjustment }\end{array}$ \\
\hline 1 & ADALAT OROS & 30.565 & 30 & 6 & 36 & 40 \\
\hline 2 & AMOXSAN 500MG & 113.49 & 114 & 22.8 & 136.8 & 140 \\
\hline 3 & SIMVASTATIN 10MG & 506.93 & 507 & 101.4 & 608.4 & 610 \\
\hline 4 & PONSTAN 500MG & 159 & 159 & 31.8 & 190.8 & 200 \\
\hline 5 & INCIDAL OD & 159.33 & 159 & 31.8 & 190.8 & 200 \\
\hline 6 & NEURALGIN RX & 226.46 & 226 & 45.2 & 271.2 & 280 \\
\hline 7 & MEFINAL & 597.74 & 598 & 119.6 & 717.6 & 720 \\
\hline 8 & ASAM MEFENAMAT & 480.31 & 480 & 96 & 576 & 580 \\
\hline 9 & CATAFLAM 50MG & 149.78 & 150 & 30 & 180 & 200 \\
\hline 10 & AMLODIPINE 5 MG & 480 & 480 & 96 & 576 & 580 \\
\hline 11 & FG TROCHES & 186.72 & 186 & 37.2 & 223.2 & 230 \\
\hline 12 & NEUROBION FORTE & 1890 & 1890 & 378 & 2268 & 2500 \\
\hline 13 & PROMAG TAB & 1752 & 1752 & 350.4 & 2102.4 & 2160 \\
\hline 14 & THERAGRAN M & 676 & 676 & 135.2 & 811.2 & 848 \\
\hline
\end{tabular}

Source: Research result (2021)

\section{Total Potential Revenue}

Improvements in inventory management system and planning calculations using forecast data will have a positive impact on amount of income obtained from Kutisari pharmacy. So based on this risk reduction, potential revenue that can be obtained from improvement of system is cost of expired goods at Kutisari pharmacy and lost sales because there is no stock which can be seen in table below

Table 6. Potential Revenue Average/Month Amount per Year

\begin{tabular}{|l|lr|rr|}
\hline \multicolumn{7}{|l|}{ Cost of expired goods } & $\mathrm{Rp}$ & 181.817 & $\mathrm{Rp}$ & 2.181 .800 \\
\hline ETHICAL (46 Product) & $\mathrm{Rp}$ & 4.483 & $\mathrm{Rp}$ & 53.800 \\
\hline NON-ETHICAL (6 Product) & \multicolumn{5}{l|}{} \\
\hline Lost Sales & \\
\hline Lost Sales Items Not Available & $\mathrm{Rp}$ & 89.700 & $\mathrm{Rp}$ & 1.076 .400 \\
\hline
\end{tabular}

Source: Research result (2021 


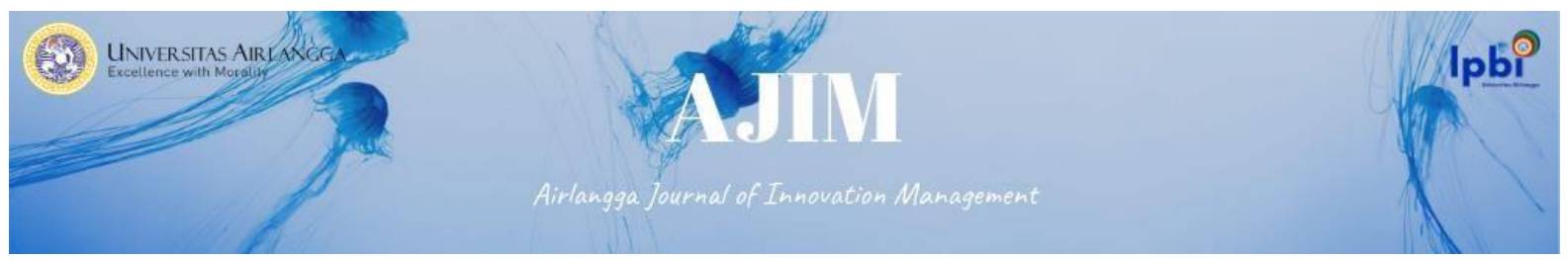

\section{Conclusion}

The design of flow and information system for pharmaceutical inventory management at Kutisari pharmacy can run well with help of an information system, so that process of recording stock and inventory can be carried out in real-time. Procurement decision making based on ABC-XYZ analysis classification and forecast time-series model can reduce risk of dead stock at Kutisari Pharmacy. The flow is designed to improve stock control problems, getting good responses from owner due to existence of an integrated information system and providing information to improve procurement accuracy due to consideration of use of goods reports and stock reports that can see previous consumption data. Application of new inventory model and flow has an impact on the potential revenue obtained from the cost of expired goods and number of lost sales due to unavailability of goods. Amount of potential annual revenue that can be obtained is Rp. 3312,000. Recommendations for further research are that it needs to be investigated further regarding other factors that cannot be obtained based on classification and forecasts using sales data for last 2 years, these factors are epidemiological factors around pharmacies that will affect drug demand and prescribing factors by local doctors which can change according to preferences of doctors around Kutisari pharmacies that can be done with a machinelearning system to calculate demand estimates and inventory management more accurately.

\section{References}

Dinas Kesehatan Kota Surabaya. (2018). Jumlah Sarana Pelayanan Kesehatan. downloaded from: http://dinkes.surabaya.go.id/portal/profil/dkk-dalam-angka/sarana-pelayanan-kesehatan/ Accessed on: 2 February 2020

Ernst, R., \& Cohen, M. A. (1990). Operations related groups (ORGs): A clustering procedure for production/inventory systems. Journal of Operations Management, 9(4). https://doi.org/10.1016/0272-6963(90)90010-B

Hutasoit, H. (2018). SISTEM INFORMASI INVENTORY OBAT BERBASIS WEB PADA APOTEK RATU MUSTIKA JAKARTA. 28.Unpublished Thesis.

Hyndman, R. J., \& Athanasopoulos, G. (2018). Forecasting: Principles and Practice. OTexts. Melbourne, Australia.2018

Ivanov, D., \& Tsipoulanidis, A. (2019). Global Supply Chain and Operations Management. http://www.springer.com/series/10099. Springer, Cham.

Kamus Besar Bahasa Indonesia (KBBI) (2016) Badan Pengembangan dan Pembinaan Bahasa, Kementerian Pendidikan, Kebudayaan, Riset, dan Teknologi Republik Indonesia https://kbbi.kemdikbud.go.id/entri/farmasi

Kementerian Kesehatan RI. (2018). Rekapitulasi Apotek Indonesia Tahun 2015- 2018. Downloaded from: http://apif.binfar.depkes.go.id/grafik-apotek.php. Accessed on 9 September 2019.

Kominfo. (2020). Revolusi Industri 4.0. https://aptika.kominfo.go.id/2020/01/revolusi-industri-4-0 Accessed on 10 September 2019.

Krishnaraj, B. R., \& K, M. P. (2016). A Study on ABC-XYZ Analysis in a Pharmacy Store. In International Journal of Mathematics and Statistics Invention (IJMSI) www.ijmsi.org (Vol. 4). www.ijmsi.org

Kumar, Y. (2017). XYZ Analysis for Inventory Management - Case Study of Steel Plant. International Journal for Research in Applied Science and Engineering Technology, 5, 46-52. https://doi.org/10.22214/ijraset.2017.2007 


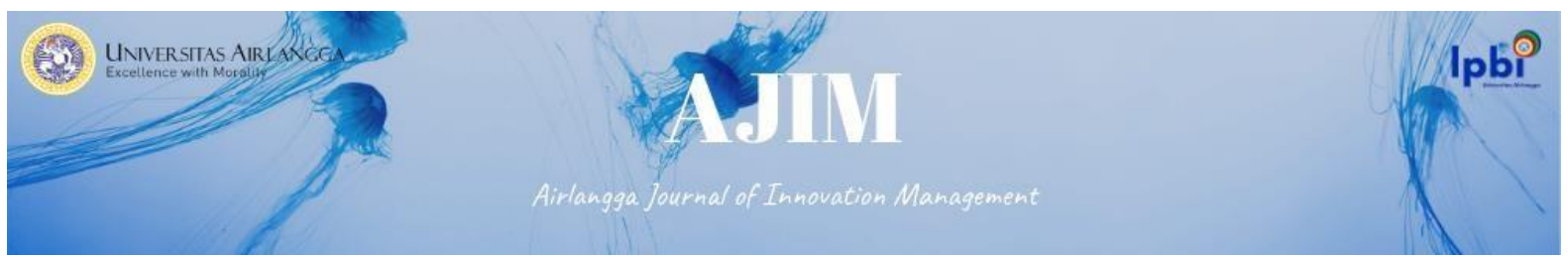

Noordstar, L., Topan, E., Supervisor, C., \& Breeuwsma, E. (2019). The Road to Forecasting Success by means of Classification A Case Study at Wavin. Unpublished Master Thesis.

Nowotyńska, I. (2013). An Application of Xyz Analysis in Company Stock Management. Modern Management Review. https://doi.org/10.7862/rz.2013.mmr.7

Pratama Wijaya, E., Gede, I., \& Widyadana, A. (2015). Klasifikasi Inventori dengan ABC/XYZ Analysis dan Mengoptimalkan Safety Stock di PT. X (Vol. 3, Issue 2).

Ravinder, H., \& Misra, R. B. (2014). ABC Analysis for Inventory Management: Bridging The Gap Between Research and Classroom. American Journal of Business Education (AJBE), 7(3). https://doi.org/10.19030/ajbe.v7i3.8635

Scholz-Reiter, B., Heger, J., Meinecke, C., \& Bergmann, J. (2012). Integration of demand forecasts in $\mathrm{ABC}-\mathrm{XYZ}$ analysis: Practical investigation at an industrial company. International Journal of Productivity and Performance Management, 61(4), 445-451. https://doi.org/10.1108/17410401211212689

Stojanović, M., \& Regodić, D. (2017). The significance of the integrated multicriteria ABC-XYZ method for the inventory management process. Acta Polytechnica Hungarica, 14(5), 29-48. https://doi.org/10.12700/APH.14.5.2017.5.3

Timm Gudehus. (2006). Dynamische Disposition. Springer-Verlag. https://doi.org/10.1007/3-54035535-9. Springer, Cham.

Trubchenko, T. G., Kiseleva, E. S., Loshchilova, M. A., Dreval, A. N., Ryzhakina, T. G., \& Shaftelskaya, N. v. (2020). Application of ABC and XYZ Analysis to Inventory Optimization at a Commercial Enterprise. SHS Web of Conferences, 80, 01007. https://doi.org/10.1051/shsconf/20208001007

Utama, R. (2019). Buku Manajemen Operasi Full.UM Jakarta Press. Jakarta.

Wang, S., \& Chaovalitwongse, W. A. (2011). Evaluating and Comparing Forecasting Models. In Wiley Encyclopedia of Operations Research and Management Science. John Wiley \& Sons, Inc. https://doi.org/10.1002/9780470400531.eorms0307 